RESENHA

\title{
Dictionnaire des concepts fondamentaux des didactiques
}

\author{
KAUÊ FABIANO DA SILVA QUEIROZ \\ Université de Lille, Lille, França
}

REUTER, Yves (Ed.). Dictionnaire des con-
cepts fondamentaux des didactiques.
3. ed. Bruxelles: De Boeck, 2013. 280p.

O dicionário "dos conceitos fundamentais das didáticas" foi publicado por uma equipe de didatas da universidade francesa Charles de Gaulle Lille 3: Bertrand Daunay, Isabelle Delcambre e Yves Reuter (especialistas em língua francesa); Dominique Lahanier-Reuter (especialista em matemática); Cora Cohen-Azria (especialista em ciências). Segundo os autores, a obra foi idealizada para suprir duas necessidades principais: reunir diferentes abordagens sobre diversos conceitos didáticos; permitir a um público acadêmico e profissional encontrar definições de base, explicações, debates e uma ampla lista de referências.

A organização do dicionário cumpre fielmente com os objetivos almejados, graças à pertinência e à coerência dos quarenta conceitos selecionados e ao tratamento original que cada um deles recebe. Os conceitos são apresentados em três ou quatro páginas, seguindo uma mesma ordem: "abordagem inicial", que os define e os contextualiza, permitindo identificá-los rapidamente; "elementos esclarecedores", que sintetizam os principais temas para a compreensão das relações subjacentes ao desenvolvimento e à aplicação dos conceitos; "questões, problemas e debates", que abordam os limites e os interesses relativos à utilização dos conceitos, de acordo com a perspectiva dos pesquisadores em educação; "elementos bibliográficos", que fazem referência às principais obras do campo.

Entre os diferentes conceitos escolhidos pelos pesquisadores da Universidade de Lille, alguns representam clássicos incontestáveis da didática: conceitos e campos conceituais; contexto e meio; contrato didático; devolução; didáticas; institucionalização; níveis de formulação; noosfera; obstáculos; práticas sociais de referência; representações; sistema didático; situações didáticas; transposição didática e triângulo didático. Outras noções mostram a preocupação dos autores em dar visibilidade às pesquisas desenvolvidas recentemente no campo francófono: consciência disciplinar; cronogênese; didática comparada e topogênese. Outros termos revelam o interesse dos autores em não privilegiar exclusivamente conceitos didáticos clássicos oriundos da matemática ou das ciências. Podem-se citar notoriamente aqueles relacionados à didática do francês: comunidade discursiva; gêneros discursivos; metalinguística; materiais; modelo didático 
e práticas linguísticas. Em uma última classificação, é possível citar noções menos específicas à didática, contudo que estabelecem um ponto de vista mais amplo em relação às questões de ensino e de aprendizagem: aluno, aprendiz, sujeito didático; aprendizagens; avaliação; conteúdos de ensino e de aprendizagem; disciplinas escolares; ensino; erro e disfunção; forma escolar; práticas extraescolares dos alunos; programação didática; relação aluno-conteúdo e tarefa. Nesta última categoria, o risco tomado é de uma certa diluição da abordagem didática em questões mais amplas da pedagogia e do ensino.

Em precisa análise, a leitura da definição atribuída ao termo "didáticas" (no plural), tal qual é defendido pela equipe de pesquisadores franceses, ajuda-nos a discernir a abordagem que norteia a obra. Em um primeiro momento, essa atribuição pode distinguir-se dos trabalhos sobre a didática no Brasil. Os autores do dicionário argumentam que as didáticas são disciplinas de pesquisa, ou seja, áreas científicas caracterizadas por questões, teorias e metodologias específicas. A pluralidade do termo faz referência às disciplinas escolares, pois elas possuem especificidades na constituição e na organização dos conteúdos curriculares e em seus desenvolvimentos nas situações de ensino e aprendizagem. Os didatas da Universidade de Lille os conceituam como saberes, saber-fazer, valores, práticas, comportamentos, atitudes, competências, entre outros, enquanto são objetos de ensino e aprendizagem, referíveis e referidos às disciplinas escolares. É nesta última perspectiva que é defendida a especificidade das didáticas em comparação a outras áreas da educação.

Fica claro no dicionário, no entanto, que as didáticas - em designação científica - não podem ser confundidas com outros tempos/espaços da didática não científica. Primeiramente, os tempos e espaços das práticas ordinárias de ensino e de aprendizagem (o professor em sala de aula ensinando determinado assunto aos alunos); em segundo lugar, os das diretrizes e dos planos de ensino que registram, em partes, o que se deve ensinar e as maneiras de ensiná-lo; por último, os das recomendações que são propostos por grupos profissionais (associações docentes, programas de formação, revistas de divulgação etc.) e que estabelecem metodologias para a seleção, organização e desenvolvimento dos conteúdos. Logo se compreende que as didáticas, como domínio científico, investigam o tempo escolar, as atividades, os professores e os alunos somente pelo prisma de suas relações com o ensino e a aprendizagem de conteúdos determinados.

Ao propor esta última percepção, a equipe francesa estabelece uma distinção entre a didática e a pedagogia. Os autores argumentam que as dimensões disciplinar, pedagógica e institucional estão indissociavelmente interligadas no âmbito escolar. Seria então por meio de uma abstração teórica que a didática e a pedagogia têm compreendido e explicado esses processos, privilegiando determinadas abordagens. As pesquisas em pedagogia se valeriam dos modelos e das metodologias de ensino e de aprendizagem e de suas inter-relações, questionando sobre as finalidades e os valores da educação; as pesquisas em didáticas encontrariam sua legitimidade ao estudar esses fenômenos pelo prisma dos conteúdos e das disciplinas escolares.

Enquanto uma vertente de pesquisadores em pedagogia tem apenas criticado as pesquisas em didática por subestimar os contextos de ensino e de aprendizagem, os didatas franceses promovem um diálogo com as pesquisas em pedagogia. Afirmam que ambas precisam uma da outra, contudo compreendem que a didática não é apenas uma disciplina oriunda da pedagogia. Nota-se, com base nos diferentes 
conceitos explorados, que a didática não se resume a uma concepção tecnicista de aplicação de conteúdos disciplinares durante as aulas.

Além de propor uma cartografia conceitual, o dicionário busca divulgar a didática em sua pluralidade de produções científicas específicas, na circulação de seus conceitos e ainda em suas reformulações e problematizações eventuais. Por assim dizer, trata-se de uma cartografia das diferentes contribuições dos didatas francófonos durante os últimos trinta anos. Destacam-se os paradigmas científicos que lhes são particulares, assim como suas concepções sociais.

Há no dicionário, no entanto, uma representação efêmera de certas disciplinas (história, geografia, educação física, sociologia, filosofia, artes) que não favorece a defesa da didática como uma área de pesquisa plural. Nesse sentido, o desenvolvimento das noções articula-se a outro ponto passível de discussão: a caracterização de conceitos em um plano predominantemente teórico. Seria pertinente apresentar exemplificações pragmáticas por meio de pesquisas reconhecidas que permitissem aos leitores melhor compreender as rupturas e as redefinições dos conceitos didáticos na perspectiva de diferentes disciplinas escolares.

Torna-se necessário destacar que esse livro tem se constituído em uma das principais referências para as pesquisas em educação de países francófonos, pois consegue desconstruir noções comuns ou que permanecem abstrusas para os profissionais da educação. A obra representa uma importante ferramenta para subverter a situação desfavorável na qual a didática encontra-se atualmente, suprindo o seu défice de legitimidade.

Ao contrário de outros dicionários científicos que frequentemente apresentam conceitos de maneira fragmentada, o livro francês é um instrumento de reflexão sobre a contribuição das didáticas ao campo da educação. A partir das múltiplas leituras que lhe são possíveis, o "dicionário dos conceitos fundamentais das didáticas" também se poderá constituir em um guia de referência(s) para os pesquisadores, professores e estudantes brasileiros.

\section{REFERÊNCIA}

Reuter, Y.(Ed.). Dictionnaire des concepts fondamentaux des didactiques. 3. ed. Bruxelles: De Boeck, 2013.280p.

\section{SOBRE O AUTOR}

Kauê Fabiano da Silva Queiroz é doutorando pela Université de Lille, EA 4354, Centre Interuniversitaire de Recherche en Education de Lille (CIREL), F-59000 Lille (França).

E-mail:kauefabiano@gmail.com

Recebido em 29 de agosto de 2016

Aprovado em 12 de setembro de 2016 